\title{
Реконструктивно-пластичні операції після поранень шиї
}

\begin{abstract}
Мета роботи: підвищити ефективність хірургічного лікування постраждалих після поранень шиї шляхом застосування реконструктивно-пластичних операцій.

Матеріали і методи. Проаналізовано результати реконструктивно-пластичних операцій у пацієнтів після поранень шиї. Втручання виконували у 82 пацієнтів: як у чоловіків, так і у жінок в одній віковій групі від 41 до 50 років. Проведено пластику місцевими тканинами та мікрохірургічну автотрансплантацію тканин.

Результати досліджень та їх обговорення. Кожен із методів має самостійне значення: пластика місцевими тканинами в різних iї варіантах усуває невеликі за площею дефекти з мінімальною втратою в донорській зоні, у свою чергу, метод мікрохірургічної автотрансплантації тканин дозволяє домогтися гарних анатомічних та функціональних результатів при великих і глибоких дефектах м’яких тканин шиї. Оцінка результатів хірургічного лікування пацієнтів показує, що в більшості спостережень вдалося отримати хороший остаточний результат (86,6 \%) - у 71 пацієнта із 82. Проте в 11 пацієнтів отримано незадовільний результат, що склало 13,4 \% від всіх пацієнтів, яким були застосовані різні методи заміщення м’якотканинних дефектів шиї після поранень.
\end{abstract}

Ключові слова: поранення шиї; реконструктивно-пластичні операції; мікрохірургічні втручання.

Постановка проблеми і аналіз останніх досліджень та публікацій. Допомога пацієнтам із післятравматичними дефектами м'яких тканин в ділянці шиї є однією з найбільш складних завдань, не тільки технічно, внаслідок анатомічних особливостей (наявності життєва важливих утворень, великих магістральних судин, нервових стовбурів та сплетінь), але і в соціальному, функціональному, естетичному плані [8].

Мікрохірургічна автотрансплантація тканин $є$ складним технічно методом та досить травматичним для донорської області [2, 6]. Пластика 3 використанням шкірно-фасціальних та шкірном'язових клаптів з осьовим типом кровообігу, викроєних в області шиї та грудної клітки, прийнятна тільки для дефектів нижньої зони обличчя i, як правило, травматична та багатоетапна [4].

Метод мікрохірургічної автотрансплантації вільних реваскуляризованих тканин на сьогодні $\epsilon$ найбільш надійним та ефективним у пластичній та реконструктивній хірургії, але саме практичний та науковий досвід дозволяє говорити про його перевагу над будь-яким іншим методом пластики з точки зору отримання найкращого результату [3, 7].

Вільні мікрохірургічні реваскуляризовані автотрансплантати мають хороше кровопостачання, операції одномоментні, а локалізація та характер ураження не обмежують використання методу [2]. Метод вільної мікрохірургічної пересадки реваскуляризованих комплексів тканин значно розширює можливості пластичної та реконструктивної хірургії, дозволяє вирішувати проблеми пластич- ного закриття великих дефектів тканин різного генезу та локалізації $[1,9]$.

Важливим моментом в лікуванні пацієнтів із великими дефектами м'яких тканин шиї є правильний вибір хірургічної тактики. На даний час у реконструктивній хірургії існують сучасні вимоги, які включають не тільки усунення від наявних вад, але й отримання хороших естетичних результатів, що сприяє адекватній соціальної адаптації в суспільстві $[5,10]$. Ми аналізували показання до різних видів пластики в області шиї, враховуючи той фактор, що кожен з методів наділений як перевагами, так і недоліками та може бути застосований в поєднанні.

Найбільш простим методом з метою заміщення дефектів м'яких тканин шиї є пластика місцевими тканинами в різних ії варіантах, яка можлива лише за наявності невеликих за площею покривних дефектів, що не зачіпають глибоких анатомічних структур [2]. Однак метод має свої обмеження і не може бути застосований при наявності великих та глибоких інфікованих дефектів м'яких тканин шиї. У таких випадках єдиним безальтернативним методом заміщення великих дефектів м'яких тканин шиї є метод мікрохірургічної автотрансплантації комплексів тканин [8].

Мікрохірургічна автотрансплантація тканин на сьогодні являє собою основний метод із заміщення великих дефектів м'яких тканин шиї, $\epsilon$ складним методом з наявністю основного етапу мікрохірургічного [3, 6].

Таким чином, різні методи мають свої плюси і мінуси для закриття дефектів шиї; на сьогодні не існує оптимального алгоритму вибору мето- 
ду закриття дефектів м’яких тканин шиї. У зв’ язку з вищесказаним, метою даного дослідження $є$ визначення оптимального алгоритму вибору методу заміщення великих дефектів м’яких тканин шиї на основі оцінки результатів застосування пластики місцевими тканинами та мікрохірургічної автотрансплантації тканин.

Мета роботи: підвищити ефективність хірургічного лікування постраждалих після поранень шиї шляхом застосування реконструктивно пластичних операцій.

Матеріали і методи. Загальна кількість пацієнтів, яким була проведена пластика місцевими тканинами - 52, чоловіків було 27 (52 \%), жінок - 25 (48 \%). Ще у 30 випадках дефекти після поранень шиї застосовувалася мікрохірургічна автотрансплантація тканин. Втручання виконували як у чоловіків, так і у жінок в одній віковій групі від 41 року до 50 років; всього 82 пацієнти.

Для усунення дефектів шиї були використані наступні види та типи реваскуляризованих автотрансплантатів: променеві - 10 (33,3 \%), торакодорсальні - 5 (16,7 \%), лопаткові - 7 (23,3 \%), клапоть з тилу стопи - 8 (26,7 \%). Великі та глибокі дефекти тканин шиї були основними причинами використання торакодорсальних тканин в якості вільного реваскуляризованого автотрансплантата для заміщення м'якотканинних дефектів. У нашій роботі перевагу віддавали різним способам місцево-пластичних операцій. Найбільш складними 3 позиції заміщення дефектів були дефекти округлої форми. Найпростішим підходом для заміщення таких дефектів було висічення навколишньої шкіри до еліптичної форми по лінії мінімального натягу. Методика, що включає в себе викроювання сусідніх трикутних клаптів із підшкірними ніжками, являє собою початковий варіант пластики за Кутлер. Дефект ромбоподібної форми з кутом $60^{\circ}$, що $є$ комбінацією двох рівносторонніх трикутників, заміщали за допомогою одиночного клаптя за Лімбергом, де заміщувалися дефекти м’яких тканин, причому форма дефекту повинна бути довгастою. М’якотканинному дефекту надається форма рівностороннього ромба з гострими та тупими кутами відповідно $60^{\circ}$ та $120^{\circ}$. Після інфільтрації м'яких тканин розчином місцевого анестетика з адреналіном проводиться розріз по ходу намічених ліній. Клапоть мобілізується та переміщається таким чином, щоб верхня його частина зайняла верхню ділянку дефекту. Проводиться фіксація клаптя на нове місце, шкіра вшивається без натягу вузловими швами монофіламентними атравматичними нитками.
Мікрохірургічна пересадка вільних реваскуляризованих автотрансплантатів являла собою кілька послідовних хірургічних маніпуляцій. За даними передопераційного обстеження визначаються показання до проведення операції із заміщення м'якотканинного дефекту. Вибір методу відновної реконструктивної операції необхідно здійснювати з урахуванням можливості застосування як мікрохірургічної автотрансплантації, так і інших методів пластики дефекту.

Результати досліджень та їх обговорення. Основними принципами при виконанні операції були досягнення найбільш прийнятного функціонального та естетичного результату після заміщення дефекту, враховуючи як безпосередні результати операції, так і подальші перспективи створення надлишку тканини для корекції, адекватний, найбільш прийнятний вибір виду та типу автотрансплантата для пластичного заміщення дефекту, грунтуючись на кожному індивідуальному випадку, правильний вибір реципієнтних судин, варіантів включення в кровотік тканинного комплексу.

Необхідне правильне ведення пацієнта в післяопераційному періоді, чіткий погодинної контроль за життєздатністю автотрансплантата, 3 метою профілактики ускладнень, проведення антибіотикотерапії як інтраопераційнно, так і в післяопераційному періоді.

Операція із мікрохірургічної пересадки вільних реваскуляризованих автотрансплантатів починається 3 анестезіологічного забезпечення, що включає катетеризацію центральної вени та інтубацію трахеї. Підготовку дефекту та реципієнтних судин здійснювали відповідно до загальних принципів судинної та відновної реконструктивної хірургії. Уражені тканини висікали в межах видимих здорових тканин, після вирішення питання про спосіб анастомозу проводили висічення дефекту. В якості реципієнтних судин використовували прилеглі судини. Ретельна підготовка реципієнтної ділянки зводила до мінімуму ймовірність виникнення ускладнень в післяопераційному періоді.

Для мікрохірургічної пересадки ми використали 30 автотрансплантатів. Вибір м’якотканинного вільного реваскуляризованого автотрансплантата здійснювали відповідно до низки чинників: необхідність застосування реваскуляризованого автотрансплантата 3 хорошим мікроциркуляторним руслом, розміри дефекту: площа, глибина дефекту; наявність інфекції в реципієнтній зоні; відстань до магістральних судин реципієнтної ділянки.

Розсікання тканин власне автотрансплантата виконували електрокоагулятором або електроно- 


\section{З ДОСВІДУ РОБОТИ}

жем, з метою виключення кровоточивості тканин. Автотрансплантат та його судинну ніжку протягом усього забору намагалися зберегти, час від часу змочували їх гепаринізованим фізіологічним розчином. При ушиванні донорського дефекту необхідно виключати надмірний натяг його країв. Для запобігання неспроможності швів та формування крайових некрозів виконували мобілізацію шкірних країв ран по периметру, а також, застосовували методи місцевої пластики та автодермопластики.

Мікрохірургічний етап включав накладання мікросудинних анастомозів із використанням мікрохірургічної техніки. Небезпека розвитку венозного тромбозу венозної системи шиї дуже висока, оскільки $є$ негативний тиск та осциляції в такт дихальним рухам - ці два фактори мають першочергове значення у формуванні даної групи ускладнень.

Таким чином, ми при накладанні венозних анастомозів «кінець у бік» обов’язково вирізали віконечко в вені, яке буде перешкоджати зіткненню губ анастомозу під час осциляції. На завершальному етапі операції проводили остаточну фіксацію автотрансплантата в реципієнтну ділянку.

У ранньому післяопераційному періоді першочергове значення набував вибір адекватного методу спостереження за пересадженим автотрансплантатом. Методом вибору ми вважаємо черезшкірне визначення напруги кисню та ультразвукову доплерографію. Критерієм адекватної перфузії при цьому є наявність венозного та артеріального шуму над судинною ніжкою. Для профілактики можливих ускладнень, як в ранньому, так і в більш пізньому післяопераційному періоді, необхідна адекватна корекція гомеостазу, проведення масивної антибіотикотерапії та повноцінне живлення. Після приживлення автотрансплантатів основне завдання - функціонально-естетичне.

Після реваскуляризації автотрансплантату спостерігали прохідність артерії автотрансплантата, венозне повернення по судинній ніжці, зміна кольору та кровоточивість тканин. Судинну ніжку кожного автотрансплантата розташовували без перегину, перекручення, натягу та вдавлення. Недостатню довжину судинної ніжки автотрансплантата в разі потреби компенсували за рахунок автовенозних вставок відповідного діаметра так, щоб вони без найменшого натягу досягли реципієнтних судин. Анастомоз із магістральними артеріями накладали завжди “кінець у бік”, або з великими гілками відповідного діаметра за типом “кінець у кінець”.

У пацієнтів з єдиним збереженим судинним пучком артеріальні анастомози накладали на різних рівнях за типом “кінець у бік”, при цьому прагнули до розташування анастомозів на різних рівнях мобілізації судини з паравазальних тканин, що, у свою чергу, дозволяло уникнути взаємного впливу деформації мобілізованої магістральної артерії та анастомозу.

Як правило, в якості шовного матеріалу використовували “пролен” або “нейлон» 8/0 або 9/0. Судини зшивали окремими вузловими або безперервним швами. Операцію проводили з використанням оптичного збільшення операційного мікроскопа.

У зв’язку з існуючою ймовірністю гострих судинних ускладнень, основним завданням будь-якої мікрохірургічної автотрансплантації в найближчі години та перші 7 діб є контроль над станом кровообігу в автотрансплантаті. Динамічне спостереження за станом кровообігу автотрансплантата ми здійснювали за допомогою дуплексного сканування з визначенням кровотоку дистальніше судинного анастомозу, оцінкою капілярної реакції та кольору автотрасплантата при наявності шкірного покриву, а при необхідності іншими верифікаційними методами контролю життєздатності автотрансплантатів (сцинтиграфія).

Для встановлення основних факторів, що визначають успіх проведення різних методів пластики, розглянуто результати операцій та лікування пацієнтів із наступних позицій: виникнення ускладнень, пов'язаних з технічними аспектами i з тактичними особливостями при виконанні пластики різними способами; вивчення функціональних та естетичних результатів.

Функціональні та естетичні результати оцінювали за критеріями вирішення задачі: реконструкції функціонально-значущої зони, зовнішньому вигляді ділянки дефекту після застосування одного із способів пластики. Оцінку отриманих результатів ми розділяли на три градації: хороший, задовільний та незадовільний.

Зважаючи, що мікрохірургічна автотрансплантація тканин є технічно найбільш складним методом пластики, кінцеві результати при заміщенні великого дефекту м’яких тканин шиї вважали несумісними з результатами при використанні будьяких інших методик пластики.

Результати операційних втручань оцінювали в терміни 1, 3, 6 місяців від дня операції.

У пацієнтів у групі з мікрохірургічною автотрансплантацією вільних реваскуляризованих автотрансплантатів, спостерігався гарний результат в 22 спостереженнях (73 \%). У 46 з 52 пацієнтів 3 пластикою місцевими тканинами післяопераційний результат оцінили як хороший, що склало 88,5 \%. Таким чином, оцінюючи результати хірур- 
гічного лікування пацієнтів, ми спостерігали, що в більшості вдалося отримати хороший остаточний результат (86,6 \%) - 71 пацієнтів з 82. Проте у 11 пацієнтів отримали незадовільний результат, що склало 13,4 \% від всіх пацієнтів, яким були застосовані різні методи заміщення м'якотканинних дефектів шиї.

Отримані результати змушують нас ретельніше ставитися до вибору того чи іншого методу пластичного заміщення дефектів шиї. На нашу думку, найбільш виправдано, при виборі методики спиратися на основні характеристики дефекту: етіологію дефекту, площу та глибину ураження, анатомічну ділянку, яку зачіпає дефект, наявність інфекційного вогнища, стан оточуючих структур та основних судинно-нервових пучків. Тільки після комплексної оцінки основних характеристик дефекту можна уникнути небажаних ускладнень та повторних операцій, обравши найбільш прийнятний метод пластичного заміщення дефектів м'яких тканин шиї. У всіх 52 пацієнтів, яким виконано пластику місцевими тканинами з метою заміщення м'якотканинного дефекту ділянки шиї, спостерігали добрий перебіг післяопераційного періоду, з первинним загоєнням ран, повним приживленням тканин. В 4 спостереженнях, що склало, 7,7 \%, спостерігали задовільний післяопераційний результат. У всіх інших 48 спостереженнях (92,3 \%) післяопераційний результат оцінений як хороший.

Iз 30 автотрансплантацій тканин, виконаних при закритті дефектів шиї, приживлення склало 86,3 \% - 25 спостережень.

Причинами невдач були: венозні тромбози 2 (6,6 \%) спостереження, артеріальний тромбоз 2 (6,6 \%) спостереження та в одного (3,3 \%) причиною незадовільного результату стало нагноєння, що супроводжувалося загибеллю автотрансплантата.

Висновки. Аналіз ускладнень, який ми отримали після проведення пластики різними методами із заміщення м'якотканинних дефектів шиї, можна зробити висновок, що при проведенні міс-

\section{СПИСОК ЛІТЕРАТУРИ}

1. Аветіков Д. С. Клініко-морфофункціональні особливості підйому та мобілізації шкірно-жирових клаптів соскоподібної ділянки / Д. С. Аветіков, Д. В. Стебловський // Актуальні питання сучасної медицини. - 2013. - Т. 13, № 2 (42). C. $180-182$.

2. Вырупаев С. В. Первичная реконструкция дефектов головы и шеи свободными и артериализованными лоскутами // Анналы пласт., реконстр. и эстетич. хирургии. - 2005. № 2. - С. 75 - 83 . цево пластичних операцій не спостерігалося жодного ускладнення, ні в одному клінічному спостереженні, що зумовлено простотою та доступністю методики порівняно з іншими способами. При цьому методика вирішує обмежені завдання.

Після виконання мікрохірургічної автотрансплантації тканин найчастіше ми спостерігали ускладнення у вигляді формування тромбозів артеріального та венозного русла. Ці ускладнення були результатом технічних похибок у період формування судинних анастомозів.

Таким чином, при виборі того чи іншого методу пластики при закритті великих дефектів м'яких тканин шиї необхідно враховувати кілька позицій: площа дефекту, наявність інфекційного процесу в ділянці дефекту, стан оточуючих дефект тканин, спроможність реципієнтних та донорських судин.

Кожен із методів має самостійне значення: пластика місцевими тканинами в різних її варіантах усуває невеликі за площею дефекти з мінімальним втратою в донорській зоні, у свою чергу, застосування методу мікрохірургічної автотрансплантації тканин дозволяє домогтися гарних анатомічних та функціональних результатів при великих і глибоких дефектах м’яких тканин шиї.

На нашу думку, при визначенні показань до вибору методу заміщення дефектів м'яких тканин шиї необхідна комплексна оцінка осередку ураження та оточуючих тканин, іншими словами локалізація, розміри, характер дефекту та його складових у сукупності.

Методика пластики місцевими тканинами проводиться з метою заміщення дефектів м'яких тканин шиї доступна, різноманітна та проста в застосуванні, але за допомогою даної методики не завжди вдається вирішити завдання, пов’язані 3 заміщенням великих за площею дефектів.

Мікрохірургічна автотрансплантація вільних реваскуляризованих тканин, безсумнівно, займає свою нішу в реконструктивній хірургії, дозволяє підвищити якість та поліпшити результативність лікування пацієнтів із великими дефектами м’яких тканин шиї.

3. Галич С. П. Замещение сложными комплексами тканей послеожоговых и посттравматических дефектов головы и шеи / С. П. Галич, Н. Ф. Дрюк, Н. Е. Повстяной // Анналы пласт., реконстр. и эстетич. хирургии. - 2002. - № 2. - С. 37 - 39.

4. Деформативно-прочностные свойства мягких биологических тканей в аспекте пластической хирургии / А. Н. Черномашенцев, Г. Д. Бурдей, М. М. Горелик [и др.] // Биомеханика кровообращения, дыхания и биологических тканей. 2004. - № 5. - С. $272-277$. 


\section{З ДОСВІДУ РОБОТИ}

5. Журавлев П. А. Применение ротационного кожно-фасциального билобарного лоскута для закрытия дефектов кожи и мягких тканей лица и головы / П. А. Журавлев, О. В. Постников // Анналы пласт., реконструкт. и эстетич. хирургии. - 2009. - № 4. - С. 90 - 96.

6. Неробеев А. И. Морфо-клиническая характеристика ангиосомных лоскутов из волосистой части головы для замещения дефектов на голове и шее / А. И. Неробеев, В. Н. Соколов, Д. С. Аветиков // Український стоматологічний альманах. - 2003. - № 2. - С. $24-26$.

7. Соколов В. М. Заміщення обширних дефектів голови комбінованими аутотрансплантатами із включенням великого грудного і найширшого м’язу спини / В. М. Соколов, Д. С. Аветіков, Р. В. Соколов // Проблеми екології та медици- ни. - 2004. - Т. 8, № 3, 4. - С. 10 - 12.

8. Трофимов Е. И. Пластическое закрытие дефектов мягких тканей головы и шеи. Микрохирургия и экспандерная дермотензия / Е. И. Трофимов, Д. М. Бжассо // Анн. пласт., реконстр. и эстетич. хирургии. - 2008. - № 1. - С. 32 - 35.

9. Hata K. The characteristics of cultured mucosae cell sheet as a material for grafting, comparison with cultured epidermal cell sheet / K. Hata, S. Kagami, M. Matsuyama // Ann. Plast. Surg. 1995. - Vol. 34, No. 5. - P. 530-538.

10. Reconstruction of the hypopharynx with the anterolatera l thigh flap: defect classification, method, tips, and outcomes / G. A. Spyropoulou, P. Y. Lin, C. Y. Chien [et al.] // Plastic \& Reconstruct. Surg. - 2011. - Vol. 127 (1). - P. 161-172.

of the skin and soft tissues of the face and head]. Annaly plast., rekonstr. i estetich. khirurgii - Annals of Plast., Reconstruction and Aesthetic Surgery, 4, 90-96 [in Russian].

6. Nerobeev, A.I., Sokolov, V.N., \& Avetikov, D.S. (2003). Morfo-klinicheskaya kharakteristika angiosomnykh loskutov iz volosistoy chasti golovy dlya zameshcheniya defektov na golove i shee [Morphological and clinical characteristics of angiosomal flaps from the scalp to replace defects on the head and neck]. Ukrainskyi stomatolohichnyi almanakh - Ukrainian Dental Almanac, 2, 24-26 [in Russian].

7. Sokolov, V.M., Avetikov, D.S., \& Sokolov, R.V. (2004). Zamishchennia obshyrnykh defektiv holovy kombinovanymy autotransplantatamy iz vkliuchenniam velykoho hrudnoho i naishyrshoho miazu spyny [Substitution of extensive head defects with combined autografts with the inclusion of the large thoracic and widest spinal muscles]. Problemy ekolohii ta medytsyny Problems of Ecology and Medicine, 8, 3, 4, 10-12 [in Ukrainian]. 8. Trofimov, E.I., \& Bzhasso, D.M. (2008). Plasticheskoe zakrytie defektov myagkikh tkaney golovy i shei. Mikrokhirurgiya i ekspandernaya dermotenziya [Plastic closure of defects in the soft tissues of the head and neck. Microsurgery and expander dermatotension]. Annaly plast., rekonstr. i estetich. khirurgii Annals of Plast., Reconstruction and Aesthetic Surgery, 1, 32-35 [in Russian].

9. Hata, K., Kagami, S., \& Matsuyama, M. (1995). The characteristics of cultured mucosae cell sheet as a material for grafting, comparison with cultured epidermal cell sheet. Ann. Plast. Surg., 34, 5, 530-538.

10. Spyropoulou, G.A., Lin, P.Y., Chien, C.Y., Kuo, Y.R., \& Jeng, S.F. (2011). Reconstruction of the hypopharynx with the anterolateral thigh flap: Defect classification, method, tips and outcomes. Plastic \& Reconstruct. Surg., 127 (1), 161-172. 


\section{RECONSTRUCTIVE PLASTIC SURGERY AFTER NECK WOUNDS}

The aim of the work: to increase the effectiveness of surgical treatment of injured after neck injuries through the use of reconstructive plastic surgery.

Materials and Methods. The results of reconstructive plastic surgery in patients after neck injuries were analyzed. Intervention was performed in both men and women in the same age group from 41 years to 50 years. Only in 82 patients local tissue repair and microsurgical tissue autotransplantation were performed.

Results and Discussion. Each of the methods has an independent value: local tissue repair in its various versions eliminates small defects in area with minimal loss in the donor area, and in turn, the use of microsurgical tissue autotransplantation technique allows achieving good anatomical and functional results with large and deep soft neck defects. Assessing the results of surgical treatment of patients, it was noted that in most cases a good final result (86.6 \%) was achieved - in 71 patients among 82. However, 11 patient received an unsatisfactory result, which amounted to $13.4 \%$ of all patients who various methods of replacing soft tissue defects of the neck after wounds were applied.

Key words: neck injuries; reconstructive plastic surgery; microsurgical interventions.

М. Ю. СИЗЫЙ, В. В. МАКАРОВ, А. Н. ШЕВЧЕНКО, В. Н. ЛЫХМАН

гУ “Институт общей и неотложной хирургии имени В. Т. Зайцева НАМНУ”

\section{РЕКОНСТРУКТИВНО-ПЛАСТИЧЕСКИЕ ОПЕРАЦИИ ПОС.ЛЕ РАНЕНИЙ НЕИ}

Цель работы: повысить эффективность хирургического лечения пострадавших после ранений шеи путем применения реконструктивно-пластических операций.

Материалы и методы. Проанализированы результаты реконструктивно-пластических операций у пациентов после ранений шеи. Вмешательство выполняли у 82 пациентов, как у мужчин, так и у женщин в одной возрастной группе от 41 года до 50 лет. Была проведена пластика местными тканями и микрохирургическая аутотрансплантация тканей.

Результаты исследований и их обсуждение. Каждый из методов имеет самостоятельное значение: пластика местными тканями в различных ее вариантах устраняет небольшие по площади дефекты с минимальной потерей в донорской зоне, в свою очередь, применение метода микрохирургической автотрансплантации тканей позволяет добиться хороших анатомических и функциональных результатов при больших и глубоких дефектах мягких тканей шеи. Оценивая результаты хирургического лечения пациентов отмечено, что в большинстве наблюдений удалось получить хороший окончательный результат (86,6 \%) - у 71 пациента из 82. Однако у 11 пациентов получено неудовлетворительный результат, что составило 13,4 \% от всех пациентов, которым были применены различные методы замещения мягкотканевых дефектов шеи после ранений.

Ключевые слова: ранения шеи; реконструктивно-пластические операции; микрохирургические вмешательства. 